\title{
INCOME DISTRIBUTION INEQUITY \\ AS THE OBSTACLE TO ECONOMIC PROSPERITY
}

\section{НЕРІВНОМІРНІСТЬ РОЗПОДІЛУ ДОХОДІВ ЯК ПЕРЕШКОДА ЕКОНОМІЧНОМУ ПРОЦВІТАННЮ}

\author{
Yuliia Erdevdi ${ }^{1}$ \\ Victor Shynkar ${ }^{2}$
}

DOI: https://doi.org/10.30525/978-9934-588-15-0-28

Abstract. An issue of worldwide income inequity attracts scientist's attention and interest. In high developed countries wages increase according to the level of productivity and are provided with its high level. In transformation economies the opposite situation occurs - labor as a factor of production is in surplus, the labor supply exceeds the labor demand, and capital, as a factor of production, is relatively scarce. Inequity leads to the stratification of the society, accumulation of wealth in the hands of oligarch, formation of financial and political elite and poverty increase.

The objective of this research is to analyse and compare the recommendations on the methods of measuring economic inequality.

The methods of comprehensive and comparative analysis and systematization are applied in this paper.

The subject of study is inequity as a worldwide economic phenomenon.

The purpose of the paper is as follows:

1) toprovide comprehensive analysis of economic schools that have made a significant contribution to the theory of distribution andredistribution of income of the population;

2) to analyze theoretical sources of substantiation of the effective mechanism of income distribution functioning on the basis of theoretical approaches to its functioning in the process of formation and development of global economy.

\footnotetext{
${ }^{1}$ Postgraduate,

Uzhhorod National University, Ukraine

${ }^{2}$ Candidate of Economic Sciences, Associate Professor,

Uzhhorod National University, Ukraine
} 
3) to discover the changing of concepts of income distribution;

4) outline the mechanisms of income redistribution in modern world economy.

The development of forms of ownership, the growth of productive forces and the complexity of the structural elements of the production process, changes in economic and social functions of the state, the volume and structure of consumption, the experience of the distribution relations in different countries have influenced the development of distributional and redistributional processes.

Global inequality is a systemic phenomenon that is the result of various socioeconomic opportunities being unused by the countries and the existing differences in the development between the countries, which significantly reduces their ability to participate in the world economic processes. A number of methods for measuring the level of inequality, which are mainly based on quantitative estimation of income inequality (consumption), are investigated.

Over the last few decades, rising income inequality has become a defining feature of social change in Western societies. This growth has not only implications for income redistribution, but also socio-cultural impact. In the context of globalization, inequality takes on a multidimensional image.

Revenue redistribution is regarded as a complex and multi-layered process that is the process of removing and transferring someone's income to others, or voluntarily transferring one's income to another.

\section{1. Вступ}

Протягом декількох останніх десятиліть зростання нерівності доходів населення стало визначальною рисою соціальних змін в західних суспільствах. Дане зростання має не тільки наслідки в напрямку перерозподілу доходів, але й соціокультурний вплив. На сьогоднішній день в науковій літературі немає чіткого виробленого розуміння соціально-економічного механізму функціонування розподілу доходів у сучасній економіці як системи взаємопов'язаних способів, форм, правил, принципів організації розподільних відносин, які визначають частку окремих людей у створеному продукті та забезпечують реалізацію низки взаємопов'язаних соціальних та економічних завдань, які сприяють ефективному розвитку суспільства та економіки. 
Ще за часів античності гострі дискусії були присвячені темі нерівності, але носили вони переважно соціальне підгрунтя. Насправді категорія нерівності виходить далеко за межі соціального виміру та зачіпає такі економічні категорії як розподіл багатства, нагромадження та концентрація багатства, приватне майно, матеріальні цінності, власність, капітал, дохід, економічна влада та вплив, засоби та фактори виробництва. Сьогодні ж нерівність як соціальне, політичне та економічне явище сягла стрімкого розвитку, зокрема, ЮНЕСКО розглядає сім проявів нерівності - економічний, соціальний, культурний, політичний, освітній, просторовий та екологічний. В умовах глобалізації нерівність приймає багатовимірний образ. Нерівномірний доступ до розподілу доходів і добробуту нерідко є відображенням інших більш глибоких аспектів нерівності. Скорочення економічної нерівності розглядається як один 3 важливих факторів забезпечення сталого розвитку.

\section{2. Нерівність як соціально-економічна категорія}

Історично склалось, що головною причиною диференціації доходів, в умовах переходу від адміністративно-командної до ринкової економіки, є швидка переорієнтація окремих суспільних груп на закони ринкової економіки, тоді як інша частина населення продовжує жити, орієнтуючись на традиційні цінності системи, яка відходить в минуле. Перехід від планової до ринкової економіки призвів до зростання рівня нерівномірного розподілу доходів в усіх країнах з так званою трансформаційною економікою. Поляризація доходів населення призвела до соціального розколу суспільства, при якому виникла прірва між елітою та основною масою населення. Ця прірва сформувалась там, де в нормальних збалансованих соціальних структурах існує середній прошарок населення. Таким чином, спостерігається розгалуження суспільства внаслідок чого формуються два протилежно спрямовані табори, які суттєво відрізняються поведінковими особливостями та спрямованістю, рівнем доходів та споживчих можливостей.

Економічна сутність нерівності розглядається з огляду на показники розподілу доходів. В даному контексті заробітна плата, як основне джерело доходу, виступає об'єктом аналізу. Однак, варто враховувати й наступні фактори: майнова нерівність, рівень кваліфікації, різниця в домогосподарствах і т.д. Диференціація доходів проявляється у відмін- 
ностях в доступі різних прошарків суспільства до власності та влади й відображається в рівні їх доходів. Об'єктивність даного явища зумовлена різними фізичними та розумовими здібностями членів суспільства, рівнем освіти та професійної підготовки, наявністю матеріальних ресурсів у розпорядженні, особистими якостями такими як здатність до ризику тощо, кількість членів родини та ії віковий склад і т.д. Диференціація доходів населення зрештою призводить до змін в соціальній структурі суспільства та розшаруванню населення за критерієм величини доходів. Дослідження та аналіз явища нерівномірного розподілу доходів серед населення нерозривно пов язані з такими економічними категоріями як дохід, багатство та бідність, а дохід, споживання та багатство є основними вимірюваними критеріями економічної нерівності. Англійський економіст Дж.Р. Гікс у своїй праці «Вартість і капітал» дає визначення категорії «дохід» як певної кількості засобів, якими володіє індивід, і які він очікує витрачати протягом наступного періоду життя. А.Сміт у своїй праці «Дослідження про причини та багатства народів» (1776) дійшов висновку, що багатство є результатом комбінації праці, землі, технологій та капіталу, які у взаємодії уможливлюють створення прибутку. Англійський економіст-класик Т. Мальтус в своїй роботі «Есе про принципи населення» (1978) зачіпав тему багатства через призму стрімкого збільшення кількості населення, що він вважав небезпекою для підтримання та зростання багатства країни. Швейцарська міжнародна фінансова група Credit Suisse визначає «багатство» як вартість фінансових активів домогосподарства плюс реальні активи (головним чином житло) за вирахуванням їх боргів [9].

Нерівність та бідність - це супутні поняття. Збільшення нерівності розподілу доходів у всіх країнах з перехідною економікою зумовили поширення бідності - явища, існування якого у командно-адміністративних економіках завжди заперечували. Організація Об'єднаних Націй $(\mathrm{OOH})$ розглядає бідність як стан вимушеної відсутності необхідних ресурсів для забезпечення задовільного стану життя. Бідність як соціально-економічне явище властива будь-якій економічній системі та пов'язана як з рівнем економічного розвитку, так і з нерівністю у доступі до матеріальних та нематеріальних благ. Однак, гострота даної проблеми в країнах різниться в залежності від типу економічної системи та темпів економічного розвитку, структури державних 
видатків, рівню накопиченого багатства та добробуту народу, розміру виробничого потенціалу, особливостей розподільної політики держави, ступеню політичної стабільності, ділового бізнес-клімату, менталітету нації, iї цінностей тощо. Кожна країна в конкретний проміжок часу використовує своє трактування бідності. У найбільш розвинених країнах світу, що орієнтуються на соціальне благополуччя своїх громадян, $\epsilon$ незначні відмінності в рівнях доходів багатих і бідних. Бідність в країнах з високим рівнем добробуту може проявлятись у відсутності коштів на товари тривалого користування, неможливістю отримання кредиту чи відсутністю доступу до професійної освіти. В країнах, що розвиваються, i країнах з перехідною економікою мають місце поляризовані суспільства, що характеризуються великою кількістю бідних, невеликим колом багатих і досить незначним середнім класом. Кожна країна в конкретний проміжок часу використовує своє трактування бідності. Так, у країнах з низьким рівнем соціально-економічного розвитку бідність віддзеркалюється у таких явищах, як голод, відсутність доступу до чистої питної води, неписьменність, висока смертність від інфекційних та паразитарних захворювань, які сучасні засоби медицини успішно лікують. Однак, це не заперечує той факт, що бідність існує завжди, вона є відносною у часі та просторі. Змін зазнають тільки іiі форми та прояви. Падіння темпів економічного розвитку в першу чергу зачіпає та дестабілізує середній клас країни, через що до прошарку бідних починають входити багато працівників престижних професій (викладацький персонал ВНЗ, професійні медики, науковці, вчителі), а в ниж-чих класах суспільства спостерігається таке явище як «зубожіння бідних».

Цікавим є припущення розмежування категорії бідних, запропоноване вченою Е. Лібановою, яка вважає, що бідність існує в двох проявах - як бід-ність «сильних» та «слабких». Остання - це бідність непрацездатних або частково непрацездатних осіб, осіб з особливими потребами. Така бідність має соціальне забарвлення, вона обумовлена демографічними особливостями окремих категорій населення. Певні прояви бідності «слабких» спостерігаються в будь-яких суспільствах. В даному випадку в гру вступає держава, функцією якої є підтримка вразливих верств на засадах соціальної допомоги. Бідність «сильних» виникає переважно в кризових умовах, коли повноцінні працездатні 
особи не з власної вини не в змозі забезпечити своєю працею прийнятні в суспільстві стандарти способу життя. У цьому контексті бідність «сильних» має переважно економічну природу. Власне тому, насамперед, потрібно будувати механізм подолання бідності «сильних», які сформують здорове, гармонійне суспільство, в якому бідність «слабких» поступово скорочуватиметься [2].

Між бідністю, спричиненою висхідною динамікою нерівності та економічним розвитком встановився певний механізм взаємозв'язку, який полягає в тому, що стрімке економічне зростання підвищує попит на робочу силу. Перехід від стану безробіття до повної зайнятості стимулює доходи тих верств, що знаходяться на нижніх щаблях суспільства, не беруть активної участі в розподілі. Це згодом призводить до зменшення нерівності. Економічне зростання сприяє накопиченню багатства, i, як наслідок, вільні ресурси можуть перерозподілятись на користь бідних, що в свою чергу також веде до зменшення розриву між багатими та бідними.

\section{3. Економічна теорія в контексті нерівномірності розподілу доходів}

В економічній теорії питання критеріїв ефективності використання ресурсів, справедливості розподілу доходів та багатства, та їх вплив на добробут розглядаються комплексно в тісній кореляції. Вперше на існування взаємозв язку між нерівномірним розподілом доходів та економічним розвитком наголосив американський вчений С. Кузнєц в 1955 році. Він зазначив, що економічне зростання спочатку призводить до збільшення нерівності, а згодом до ії зменшення. Цей взаємозв язок отримав назву крива Кузнєца (зворотня U-крива). Теоретичне обгрунтування кривої Кузнєца полягає в тому, що в країнах з раннім ступенем економічного розвитку нерівність доходів спочатку зростає, але згодом має тенденцію до зменшення. Вчений висунув гіпотезу, що нерівномірність у виробництві призводить до високого рівня доходів в індустріальному секторі і, як наслідок, збільшенню його долі в економіці та зростанню нерівності. За основу дослідження вченим взято двохсекторну економіку, в якій одна галузь (наприклад, сільське господарство) $є$ більш технологічно відсталою порівняно з іншою (промисловість). Першочергово перша галузь (сільське господарство) 
переважає в економіці країни, відповідно більшість населення зайнята в даному секторі, а дохідна частина перебуває приблизно на одному рівні i, таким чином, встановлюється відносна рівність в суспільстві. Проте, поступово доля іншого сектору (в конкретному випадку промисловості) зростає, а в силу високої продуктивності праці заробітна плата встановлюється на вищому рівні порівняно з іншою галуззю, що сприяє перетоку робочої сили. Припускається, що заробітна плата в останній галузі може бути неоднорідною, тому що спочатку спостерігається приплив некваліфікованої робочої сили. Ці фактори призводять до росту нерівності як всередині галузі, так і в економіці в цілому. Цей процес продовжується до тих пір, поки в першій галузі не залишиться занадто мала кількість робітників, що призведе до підвищення заробітної плати в галузі. Крім того, успішність другої галузі сприятиме підвищенню продуктивності праці в першій галузі, а робітники, що перейшли з першої галузі в другу на той час вже отримають необхідний обсяг знань та професійного досвіду. Перерозподіл робочої сили з галузей з низькою продуктивністю праці в галузі з більш високою продуктивністю праці призводить до поступового виникнення та закріплення тенденції на зниження нерівномірності доходів. Все це призведе до підвищення доходів в обох галузях, а на загальноекономічному масштабі - до зниження нерівності та підвищення суспільного добробуту. Дане твердження не має остаточного наукового схвалення, адже існують різні точки зору науковців стосовно підтвердження наявності цього взаємозв'язку. Зокрема більшість сучасних науковців не прослідковують існування будь-якого взаємозв'язку між економічним розвитком та розподілом доходів населення.

Представники різних економічних шкіл та економічної думки за основу дослідження брали певні аспекти розподільних відносин, рівень розвитку продуктивних сил, специфіку відносин власності, наявні механізми впливу держави та інших суспільно-політичних інститутів на розподіл доходів в суспільстві.

Класична школа, представлена такими вченими як А. Сміт, Д. Рікардо, Дж.С. Мілль, Е. Берк, Дж. Прістлі, Дж. Бентам, А. Юнг, в контексті розподілу та перерозподілу доходів населення розглядає суспільство як цілісну єдність, де кожен член суспільства має свою частку в національному доході. Добробут суспільства в повній мірі впливає 
на добробут і щастя окремого індивіда. Зростання національного багатства впливає на зростання життєвого рівня громадян. Вільне підприємництво повинно забезпечувати зростання національного багатства і тому воно отримує гарантії недоторканості в державній політиці невтручання. Розмір зарплати А. Сміт визначав виходячи із вартості засобів існування: «Людина завжди повинна мати можливість існувати своєю працею, і ії заробітна платня мусить щонайменше бути достатньою для іiі існування. У більшості випадків вона має навіть перевищувати цей рівень; в іншому разі робітник не мав би можливості утримувати сім'ю» [4, с. 47].

«Структура розподілу, - стверджував К. Маркс, - повністю визначається структурою виробництва. Розподіл сам є продуктом виробництва - не лише за змістом, бо розподілятися можуть лише результати виробництва, але і за формою - бо певний спосіб участі у виробництві визначає особливу форму розподілу, форму, в якій беруть участь в розподілі».

К. Маркс та К. Каутський, представники марксизму, припускали, що зростання продуктивності праці, досягнуте при капітальному способі виробництва, даючи вигоди капіталісту, не звільняє робітників від всезростаючої бідності.

Маржиналісти Л. Вальрас, К. Менгер, Е. Бем-Баверк, Л. Візер, Дж.Б. Кларк, відштовхуючись від теоретичних засад граничної корисності, стверджували, що:

- фактори виробництва створюють національний дохід і беруть участь у його привласненні;

- прибуток $є$ платою за використання такого фактору як підприємницький хист;

- існує природний закон розподілу, згідно з яким кожен економічний суб'єкт має свою винагороду.

Економічна школа інституціоналізму (Т. Веблен, В. Комонс, В. Мітчел, В. Гамільтон, А. Берлі, М. Туган-Барановський, В. Льюїс, Я. Таката) розглядає чинником у визначенні розміру заробітної плати продуктивність суспільної праці, яка визначає обсяг суспільного продукту, що підлягає розподілу між суспільними класами та соціальною силою робітничого класу, від якої залежить частка суспільного продукту, яка надходить у розпорядження робітника. 
М. Туган-Барановський стверджував, що «чим більше згуртовані робітники, тим вони економічно сильніші по відношенню до капіталістів і тим більшу частку свого продукту можуть відстояти у боротьбі 3 останніми».

Дж. Кейнс («Загальна теорія зайнятості, процента і грошей», 1936 р.) констатував факт, що багатство розподіляється між членами суспільства нерівномірно, що $є$ пороком економіки. Вирішення проблеми вчений вбачав у встановленні чіткого оподаткування, зокрема введення податку на спадщину, що допоможе усунути нерівність у розподілі багатства.

В. Парето,один із видатних та знаних дослідників, у 1897 р. сформулював універсальний принцип, названий в економічній теорії «законом Парето», або «принципом 20/80». На той час науковцем за основу дослідження було взято тогочасну структуру розподілу доходів населення Італії, та встановлено наступну пропорцію: 20\% населення зосереджує у своїх руках $80 \%$ сукупного доходу, тоді як $80 \%$ населення отримує тільки 20\% доходу. Закон Парето твердить, що, незважаючи на соціальні та політичні фактори, форму правління, нерівномірність розподілу доходів залишається стійкою для усіх країн, а їі величина (пропорція 20/80) скрізь майже однакова. Покращення на думку В.Парето наступає тоді, коли підвищення добробуту одних людей не погіршує добробут інших. Учений шукав джерела добробуту суспільства у сфері державних фінансів, вважаючи, що через бюджетно-податкову політику держава має забезпечу-вати реалізацію демократично визначених етичних ідеалів. Принцип нерівномірного розподілу не обмежується межами фінансової площини. Якщо вдатись до детального вивчення даного питання, то насправді значний обсяг наукових робіт публікує невелика кількість вчених, а невелика група композиторів $\epsilon$ творцями майже всієї класичної музики, відомої в сучасному світі.

Економісти Реймонд Фісман і Едвард Мігел в своїй книзі «Економічні Гангстери: Корупція, Насильство і Бідність Народів» зачіпають тему нерівності та висувають нову теорію про нездатність бідних держав вибратися з хронічної бідності. Теоретичні витоки хронічної бідності лежать в основі двох теорій:

1) бідні країни позбавлені стартового капіталу, необхідного для розвитку, а кредитні ресурси призводять тільки до збільшення боргів. 
Виходячи 3 цього, бідним державам слід допомагати шляхом надання ім економічної допомоги та списання боргів;

2) головна причина бідності держав - поганий уряд. Корумповані чиновники і політики зацікавлені в особистому збагаченні, їх не цікавить громадське процвітання. У результаті, міжнародна допомога не виправдовує себе, оскільки потрапляє в кишені місцевої еліти, а не тих, хто її потребує. Допомогти бідним державам вибратися з нужди, можна тільки шляхом проведення комплексних реформ і лише після цього - надання економічної допомоги.

Р. Фісман і Е. Мігел висунули свою теорію, в якій пояснили бідність держав як схильність їх мешканців до традиційного насильства і недотримання законів. До прикладу, результати дослідження ситуації з рівнем насильства в Африці показали, що саме в періоди посухи і голоду насильство серед населення має тенденцію до зростання. Логічне пояснення цьому наступне: за умов коли селянин позбавлений можливості займатися сільським господарством різко збільшується ймовірність того, що він стане схильним до пограбування. В такому випадку кількість грабежів серед населення зростає, тим самим позбавляючи сенсу роботи інших селян і скорочуючи розміри інвестицій в економічних масштабах (наприклад, люди не зацікавлені будувати будинки, придбавати матеріальні цінності, адже побоюються, що їх пограбують або спалять). Як наслідок, жителі у безвиході: голод породжує насильство, а насильство - голод.

Прийнято вважати, що від насильства найбільше потерпають держави, заселені представниками різних національностей, - різні етноси таким чином воюють за вплив. Однак в Сомалі, населення якої сповідує одну релігію і належить до однієї етнічної групи, насильство не припиняється вже кілька десятиліть. На думку Р. Фісмана та Е. Мігела в бідних державах існує давня традиція насильства і недотримання закону, в тому числі, який проявляється у поширенні корупції.

T. Пікетті, французький економіст, у своїй книзі «Капітал у XXI сторіччі» (2013 р.) прогнозує тенденцію до зростання концентрації багатства, тому що нині рівень прибутковості капіталу значно перевищує рівень та темпи економічного зростання. Дохід на капітал генерує більший рівень багатства ніж доходи від заробітної плати, що веде до концентрації капіталу. Економістом висунуто ідеї подолання 
даної проблеми шляхом введення прогресивного податку на доходи та податку на багатство.

Перерозподіл доходів - це складний та багатошаровий процес, який являє собою процес вилучення частини доходів у одних та передачу їх іншим, або добровільне передавання доходів одних іншим, у випадку держави - через податки, у межах галузі - через бюджет, у межах сім’ї - через розподіл загального доходу сім “̈ між ії членами. Перерозподіл доходів може приймати кілька форм. Перша - це прямий перерозподіл доходів від багатих прошарків суспільства на користь бідних. Друга форма здійснюється 3 допомогою державного втручання шляхом фінансування та забезпечення неблагополучних верств суспільними благами (освіта, пенсійне забезпечення, охорона здоров`я, забезпечення житлом тощо).

На думку Н. Холода нині не існує єдиної теорії, яка цілком та вичерпно пояснює процеси розподілу доходів населення у сучасних економічних системах, тому потрібно використовувати різні підходи [6, с. 26].

Раніше вважалось, що саме нерівність стимулює економічний розвиток. Пояснення даному твердженню наступне: нерівність сприяє накопиченню капіталу в представників багатих верств суспільства, 3 допомогою якого стимулюється подальше економічне зростання. Проте, на сьогоднішінй день сміливо можна спростувати дане твердження, адже, навпаки, саме зменшення нерівності сприяє економічному росту. Перш за все, нерівність здійснює негативний вплив на економічне зростання, тому що малозабезпечені громадяни позбавлені можливості накопичувати свій матеріальний та людський потенціал, що призводить до негативних наслідків в довгостроковій перспективі. По-друге, нерівність також може стати причиною соціально-політичної нестабільності в країні, що веде до зменшення інвестицій та капіталовкладень, і в результаті до економічного занепаду. По-третє, нерівномірний розподіл доходів в суспільстві може мати негативний політекономічний вплив на ситуацію в країні. Наприклад, в країнах 3 великим розривом між багатими та бідними владні сили вдаються до популістських мір в напрямку перерозподілу доходів, спостерігається масова експропріація, що послаблює мотиви до накопичення, капіталовкладень та праці, що супроводжується загостренням політичної 
ситуації та підривом економічного розвитку. По-четверте, тенденція нерівномірного розподілу цінних ресурсів свідчить про всезагальну загрозу стабільності суспільства. Надмірна диференціація доходів населення посилює соціальну та політичну нестабільність суспільства, тому питання боротьби з бідністю безпосередньо пов'язане з проблемою перерозподілу доходів та забезпечення соціальної справедливості. Найбільш вразливим виступає середній клас, стимулюючий вплив якого на економічний розвиток значно послаблюється. Бідність та убогість викликають зростання соціальних захворювань, професійну деградацію та погіршення якості людського капіталу. Висока диференціація доходів посилює підприємницькі та інвестиційні ризики. Але при перерозподілі доходів у суспільстві з метою досягнення більшої соціальної справедливості можливе зниження стимулів до активної економічної діяльності членів суспільства. Витрати на реалізацію перерозподільних програм можуть перевищити вигоди від їх здійснення. Тому особливо важливим у таких умовах $є$ формування соціальних нормативів, тобто - мінімальних державних гарантій, а саме: прожитковий та неоподатковуваний мінімум, мінімальні розміри заробітної плати, допомоги, пенсії за віком, співвідношення прожиткового мінімуму та мінімальної заробітної плати, пенсії.

\section{4. Практичні підходи до вирішення проблем нерівності}

Як вже наголошувалось, нерівномірний розподіл має глобальний характер та притаманний всім країнам. Для оцінки рівня даного явища застосовують «індекс Джині» - макроекономічний коефіцієнт, розроблений статистиком італійського походження К. Джині. Даний показник визначає диференціацію населення за рівнем грошових доходів та вказує на ступінь відхилення фактичного розподілу доходів від абсолютно рівного розподілу. ООН, Світовий банк та інші відомі та впливові міжнародні організації застосовують даний коефіцієнт для розрахунку стану розподілу доходів населення в розрізі країн світу. Значення коефіцієнту коливається від 0 (або 0\%) до 1 (або 100\%). Якщо країна має нульовий показник коефіцієнту Джині, то відповідно до вимірювання розподілу багатства країна має ідеальну рівність з точки зору фінансового процвітання. Якщо ж коефіцієнт Джині в країні рівний одиниці, то країна має найбільший прояв нерівності та непропорцій- 
ний розподіл багатства серед своїх жителів. Таким чином, найкращий сценарій для країни - це нульове значення індексу Джині. Більшість науковців схильні вважати, що індекс Джині не є абсолютно правильним засобом вимірювання доходу чи багатства країни. Країна 3 високим рівнем доходу та країна 3 низьким рівнем доходу можуть мати однаковий показник індексу Джині, так як доходи розподіляються однаково всередині цих країн [7].

В більшості випадків ступінь нерівності визначається через систему показників, заснованих на статистичних оглядах та розрахунках, які пов'язані з пошуком та встановленням функціональних залежностей. У доповіді ПРООН подають статистику за децільним та квінтильним коефіцієнтами щодо оцінки нерівності у рівнях споживання (доходу). Найбільш простим показником нерівності є децільний коефіцієнт відношення середнього доходу найбагатших 10\% населення до середнього доходу найбідніших 10\% населення. Значення цього коефіцієнта в різних країнах коливається в межах від 5 до 106.

Квінтильний коефіцієнт - співвідношення мінімального рівня доходів серед найбільш забезпечених 20\% населення до максимального рівня доходів серед найменш забезпечених 20\% населення, ранжованого за показником середньодушових еквівалентних доходів. Середнє значення квінтильного коефіцієнту сягає позначки 6,6 пунктів.

У новітніх дискусіях про нерівність на глобальному рівні до показників вимірювання нерівності відносять показник істинних заощаджень і багатства, який був запропонований Світовим банком, економіко-математичні показники оцінки нерівності: індекс генералізованої ентропії (GE - Generalised Entropy index), який був запропонований нідерландським економістом Анрі Тейлом у 1967 році на підставі доходів (споживання) на душу населення; індекс А. Аткинсона; індекс розвитку людського потенціалу (далі - ІРЛП), індекс щастя та ін. [12; 13; 16$]$.

Політика Європейського Союзу спрямована на розбудову моделей багаторівневого державного управління для забезпечення більш досконалого соціального захисту малозабезпечених груп населення (одинокі матері, безробітні, «працюючі бідні»), зменшення бідності та соціальної ізоляції.

Прагнення побороти нерівність стимулює держави впроваджувати різні інструменти, такі як оподаткування та регулювання державних 
витрат. Застосування вищезазначених інструментів та методи їх поєднання 3 принципами соціально-економічної рівності обумовлюють особливості соціальної моделі країни. Соціальна модель країн Європи початком свого формування сягає кінця XIX ст. та орієнтована на підтримання відносної стабільності та гармонії, мінімізація соціальної напруги, уникнення кризових демографічних та економічних зрушень.

\section{5. Сучасні тенденції та особливості розподілу}

\section{доходів та багатства серед населення}

Сьогодні зростаюча нерівність в доходах індивідів характерна всім країнам світу із очевидною тенденцією до погіршення. Можна стверджувати, що дана проблема займає одну з передових позицій 3-поміж наявних проблем людства. Якщо раніше проблема нерівності стосувалась тільки бідних країн, то станом на сьогодні вона зачіпає навіть розвинуті країни, які вже розробили власні підходи до даного питання. До прикладу, США зосереджують зусилля на розбудові стовпів капіталізму, який, в свою чергу, має забезпечити економічну та соціальну рівність. В США бідність розглядають як особистий добровільний вибір людини, тому державна допомога надається всім потребуючим в однаковому розмірі та не забезпечує надто комфортні умови для існування. Інша ситуація спостерігається в скандинавських країнах, де робиться колосальний акцент на всезагальній рівності та всім гарантовано високий рівень соціального захисту, незважаючи на робочий стаж та сплачені соціальні внески.

Проте ситуація залишає бажати кращого. За результатами дослідження міжнародної благодійної організації «Охfam», за 2018 рік статки мільярдерів зросли на $12 \%$. Після світової фінансової кризи 2007-2008 рр. кількість мільярдерів у світі подвоїлася і досягла цифри 2208 осіб, а їх сумарні статки збільшуються на 2,5 млрд. дол. щоденно, в той час як ставки оподаткування для найбільш багатих осіб та корпорація держави зменшили до мінімуму за останні 10 років [11].

Розрив між багатіями та бідними росте щодня. Країни намагаються зменшити кількість людей, які живуть в крайній бідності, однак економічний розрив продовжує зростати, а найбагатші люди світу надалі накопичують безпрецедентні обсяги багатства. Oxfam припускає, що інвестиції в освіту, охорону здоров'я та соціальне страхування можуть 
зробити істотний внесок у викорінення бідності та нерівності, однак подібних вкладень у всьому світі катастрофічно не вистачає.

Дослідження провідних міжнародних організацій свідчать, що сотні мільйонів людей по всьому світу живуть в стані крайньої бідності, тоді як величезні матеріальні винагороди випадають тим, хто знаходиться на вершині суспільного ладу. Мільярдерів стає дедалі більше, ніж будь-коли раніше, і їхні статки виросли до рекордного рівня, в той час як бідні стали ще біднішими. Уряди країн називають цю ситуацію справжньою світовою кризою. Урядове втручання шляхом оподаткування могутніх корпорацій та заможних осіб здійснюється в рамках регулювання рівня розподілу багатства серед населення, але недостатне фінансування соціальних програм (охорона здоров я, освіта) призводять до того, що від такого роду політики потерпають бідні.

$1 \%$ найбагатших у світі людей, статки яких перевищують 1 мільйон доларів, належить $45 \%$ світового багатства. Люди зі статками менше 10000 доларів становлять 64\% світового населення, але отримують менше $2 \%$ світового багатства. До багатих людей відносять людей, статки яких перевищують 100 000,00 дол. США. Найбагатші люди світу складають менше $10 \%$ населення планети та володіють $84 \%$ світового багатства [8].

За даними Forbes, 10 топ-мільярдерів світу мають 745 мільярдів доларів сукупного багатства, що перевищує загальну кількість товарів і послуг, які виробляє більшість країн щорічно. Станом на 2018 рік згідно 3 рейтингом Forbes загалом у світі проживає 2208 мільярдерів. Тi, хто мають надзвичайні статки, часто накопичували їх на спинах тих людей, які працюють на низьку заробітну плату та в небезпечних умовах.

Починаючи 31980 р. частка національного доходу, який припадає на найбагатший 1\%, швидко збільшується в Північній Америці (а саме в США та Канаді, Китаї, Індії та Росії та більш помірковано в Свропі. Справа в тому, що в післявоєнні роки політики країн на зменшення економічних розривів були відкинуті з порядку денного стабілізації ситуації в світі. На відміну від цього, країни та регіони, які не зазнали повоєнного режиму, такі як Близький Схід, Африка на південь від Сахари та Бразилія, мали відносно стабільний, але надзвичайно високий рівень нерівності. Швидке економічне зростання в Азії (особливо в Китаї та Індії) вивело багатьох людей з крайньої бідності. У Китаї спостеріга- 
ється найшвидше зростання частки світових мільйонерів, піднявшись з 5\% в 2017 році в частці мільйонерів усього світу до 7\% в 2018 році.

Станом на 2019 рік 1\% найбагатших в США володіють 42,5\% національного багатства, що становить значно більшу частку, ніж в інших країнах ОЕСР. У жодній іншій індустріальній країні найбагатший $1 \%$ не володіє більше ніж 28\% багатства своєї країни. В США майже 5,3 мільйона осіб володіють фінансовими активами щонайменше 1 млн. дол. США.

Понад 65\% світових мільйонерів продовжують проживати в Свропі чи Північній Америці, з них 41\% називають своєю домівкою США [17].

Тенденції та особливості розподілу багатства в сучасному світі:

1. Бум світових мільярдерів. Минуло трохи більше 10 років 3 моменту фінансової кризи, яка сколихнула світ і заподіяла величезні страждання. За цей час статки найбагатших різко зросли, а кількість мільярдерів збільшилася майже вдвічі. У 2017 та 2018 роках список мільярдерів поповнювався на 1 пункт кожні два дні. Сьогодні в їхньому розпорядженні більше багатства, ніж будь-коли раніше, в той час як майже половина людства ледве врятувалась від крайньої бідності, живучи менше ніж на 5,50 доларів на день.

Прийнято вважати, що зростання кількості мільйонерів провокує зрос-тання нерівності серед населення. Зміни в рівні нерівності, або точніше зміни в частині розподілу, безумовно, може бути фактором, який впливає на збільшення або зменшення відносного багатства тих, хто перебуває на вершині добробуту. Однак, є й інші фактори, що сприяють зростанню кількості мільйонерів: зростання середньозваженого показника багатства допомагає індивідуумам перейти поріг в 1 млн. дол. США, а зростання чисельності населення розширює потенційне коло тих, хто зможе перейти вищевказаний поріг. [CreditSuisse]

2. Недофінансовані державні послуги. Державні інституції страждають від хронічного недофінансування або підпадають під дію приватних компаній. У багатьох країнах гідна освіта або якісна охорона здоров'я стали розкішшю, яку можуть собі дозволити лише багаті. Це має важливе значення для майбутнього покоління та можливостей прожити краще та довше життя.

3. Якість життя. У більшості країн гроші є засобом здорового та тривалого життя. Люди з бідних громад можуть сподіватися померти 
на десять-двадцять років раніше, ніж люди у заможних районах. У країнах, що розвиваються, діти з бідних сімей вдвічі частіше помирають у віці до п'яти років, ніж діти із забезпеченої родини.

4. Гендерна нерівність. У багатьох країнах простежується диспропорція на рівні гендерних доходів на ринку праці. Наприклад, в Америці середня заробітна плата для жінок складає 77\% від заробітної плати чоловіків [1].

Чоловіки володіють на 50\% більше світового багатства, ніж жінки, i контролюють $86 \%$ корпорацій. Тільки 4 центи на кожен долар податкового доходу надходять від податків на багатство. За 2018 рік багатство світових мільярдерів перевищило 900 мільярдів доларів, що становить 2,5 мільярда доларів на день [17].

Відповідно до звіту Gredit Suisse, оприлюдненого в жовтні 2019 року, глобальні розриви в рівні багатства скорочуються протягом останніх двох десятиліть. Єдиною групою, яка намагається протистояти цій тенденції, є верхівка світу, що становить не більше 5\% світового населення. Припущення про те, що більшість людей покращили своє відносне становище багатства підкріплюється спостереженням, що частка небагатих, тобто 90\% світового населення, у структурі світового багатства зросла від 11,5\% у 2000 році до 18,3\% у 2019 році. Вплив приросту населення на нерівність в розподілі багатства - це ще одне питання, на яке варто звернути увагу. Приріст населення зменшує відносну кількість дорослих, які в середньому заможніші за молодих, тому це підтримує тенденцію до зменшення нерівності багатства або ж обмеження до його збільшення [9].

\section{6. Висновки}

Таким чином, між реальною та видимою проблемою нерівності існують суттєві відмінності. Нерівність, як мультиаспектна категорія, існує на всіх рів-нях: національному, регіональному та глобальному. Економічна нерівність проявляється в нерівномірному доступі до економічних ресурсів: доходів, активів, власності, багатства, капіталу між різними верствами населення країни, регіону, світового господарства. Нерівність сприймається через призму відносності та відмінностей у можливостях розвиватися. Тому для іiї оцінки традиційно використовують показники концентрації доходів, багатства, активів: коефіцієнт 
Джині, Пальми, децільний та квінтильний показники, індекс щастя, ВВП на душу населення та ін. Різні представлення про нерівність суттєво різняться між собою та, іноді, протирічать фактичним даним (рейтинг про щастя та ін.). Комплексний та цілісний аналіз показників нерівності дає можливість чітко виокремити підстави, розробити й сформувати заходи щодо скорочення нерівності.

В сталих економічних системах уряд зменшує нерівність в доходах та бореться з бідністю громадян шляхом грамотного та ефективного перерозподілу доходів. Масштаби зазначеного перерозподілу мають історичні витоки, залежать від типу економічної моделі в країні, політичної ситуації, цінностей, закладених в суспільстві та багатьох інших факторів. В країнах 3 трансформаційною економікою дане питання набуло особливої важливості та актуальності, адже власне перехід від принципів командної економіки до ринкових механізмів - це процес складний та тривалий.

Відносини з розподілу доходів формуються на рівні взаємодії багатьох суб'єктів (індивідів, груп людей, домогосподарств, держави, суспільства в цілому), де об'єктом виступає результат суспільного виробництва (товари, послуги), необхідний для задоволення потреб учасників відносин. Розробка та введення механізмів формування доходів на різних рівнях та їх розподілу між представниками різних соціальних прошарків. Даний аспект $\epsilon$ вирішальним у встановленні оптимального співвідношення ефективності та справедливості розподілу.

\section{Список літератури:}

1. Дучинська Н.І. Диференціація доходів домашніх господарств в умовах ринкової економіки. Матеріали Міжнародної науково-практичної конференції «Сучасний стан та проблеми розвитку статистики, обліку та аудиту в умовах глобалізаиії». Дніпропетровськ, 2015. 146 с.

2. Лібанова Е.М. Бідність населення України: методологія, методика та практика аналізу : моногр. Київ : КНЕУ, 2008. 330 с.

3. Рикардо Д. Начала политической экономии и налогового обложения / Антология экономической класики. Т. 1. Москва : Экономключ, 1991.

4. Сміт А. Добробут націй. Дослідження про природу та причини добробуту націй; перекл. $з$ англ. [О. Васильєва, М. Межевікіної, А. Малівського]. Київ, 2001. 593 с.

5. Туган-Барановський М.І. Основи політичної економії. Львів : ЛНУ м. I. Франка, 2003.

6. Холод Н.М. Розподіл доходів та бідність у перехідних економіках : монографія. Львів : Вид. центр ЛНУ ім. Івана Франка, 2009. 442 с. 
7. Gini Coefficient By Country Population. URL: http://worldpopulationreview.com/ countries/gini-coefficient-by-country/ (дата звернення: 30.10.2019).

8. Global inequity facts.Inequality.org. URL: https://inequality.org/facts/globalinequality/ (дата звернення: 30.10.2019).

9. Global wealth report 2019. Credit Suisse. Research Institute, October 2019. URL: https://www.google.com/url?sa=t\&rct=j\&q=\&esrc=s\&source=web\&cd=2\& cad $=$ rja\&uact $=8 \&$ ved $=2$ ahUKEwjp55vh8MPlAhXpyKYKHUroDqwQFjABegQI CxAG\&url=https\%3A\%2F\%2Fwww.credit-suisse.com\%2Fmedia\%2Fassets\%2F corporate $\% 2 \mathrm{~F}$ docs $\% 2$ Fabout-us $\% 2$ Fresearch $\% 2$ Fpublications $\% 2$ Fglobal-wealthreport-2019-en. pdf\&usg=AOvVaw2VwCNo8WRWHRSaFABx_Sr8 (дата звернення: 30.10.2019).

10. Oxfam Briefing Paper (2017). AN ECONOMY FOR THE 99\%). URL: $\quad$ https://www.oxfam.org/sites/www.oxfam.org/files/file_attachments/bpeconomy-for-99-percent-160117-en.pdf (дата звернення: 30.10.2019).

11. Oxfam: World's richest 26 own same wealth as poorest half. URL: https://www.aljazeera.com/news/2019/01/oxfam-world-richest-26-wealthpoorest-190121054249908.html (дата звернення: 30.10.2019).

12.The Changing Wealth of Nations: Measuring Sustainable Development in the New Millennium. Environment and Development. World Bank, 2011. URL: https://openknowledge.worldbank.org/handle/10986/2252 (дата звернення: 30.10.2019).

13. Theil H. Economics and Information Theory. Amsterdam: North- Holland, 1967. $488 \mathrm{p}$.

14. World Development Report 2019. URL: https://www.worldbank.org/en/ publication/wdr2019 (дата звернення: 30.10.2019).

15. World GDP per capita Ranking 2019. URL: http://statisticstimes.com/ economy/projected-world-gdp-capita-ranking.php (дата звернення: 30.10.2019).

16. World Happiness Report 2019. URL: https://www.google.com/url?sa=t\&rct=j\&q= \&esrc $=$ S\&source $=$ web\&cd $=4 \&$ cad $=$ rja\&uact $=8 \&$ ved $=2$ ahUKEwjVl C1-PPIAhVmyqY KHaYpCgkQFjADegQIABAB\&url=https $\% 3 \mathrm{~A} \% 2 \mathrm{~F} \% 2 \mathrm{Fw}$ orldhappiness.report $\% 2 \mathrm{Fed} \%$ 2F2019\%2F\&usg=AOvVaw1n8QVn6lkvFQgkypc08TO- (дата звернення: 30.10.2019).

17. 5 shocking facts about extreme global inequality and how to even it up. Oxfam international. URL: https://www.oxfam.org/en/5-shocking-facts-aboutextreme-global-inequality-and-how-even-it (дата звернення: 30.10.2019).

\section{References:}

1. Duchynsjka N.I. (2015). Dyferenciacija dokhodiv domashnikh ghospodarstv v umovakh rynkovoji ekonomiky [Uneven income distribution in a market economy]. Proceedings of the Mizhnarodna naukovo-praktychna konferencija "Suchasnyj stan ta problem rozvytku statystyky, obliku ta audytu v umovakh ghlobalizaciji» (Dnipropetrovsjk), Dnipropetrovsjk. (in Ukrainian)

2. Libanova E.M. (2008). Bidnistj naselennja Ukrajiny: metodologhija, metodyka ta praktyka analizu: monoghr. [Poverty in Ukraine: methodology, methods and practice analysis: monograph]. Kyiv: KNEU. (in Ukrainian) 
3. Rikardo D. (1991). Nachala politicheskoy ekonomii $i$ nalogovogo oblozheniya / Antologiya ckonomicheskoy klasiki. T. 1 [Principles of Political Economy and Taxation, T. 1]. Moskow: Ekonomklyuch. (in Russian)

4. Smit A. (2001). Dobrobut nacij. Doslidzhennja pro pryrodu ta prychyny dobrobutu nacij [The Wealth of Nations]. Kyiv. (in Ukrainian)

5. Tughan-Baranovsjkyj M.I. (2003). Osnovy politychnoji ekonomiji [Political Economy]. Lviv: LNU im. I. Franka. (in Ukrainian)

6. Kholod N.M. (2009). Rozpodil dokhodiv ta bidnistj u perekhidnykh ekonomikakh: monoghrafija [Income Distributionand Poverty in Transitional Countries]. Lviv: Vyd. centr LNU im. Ivana Franka. (in Ukrainian)

7. Gini Coefficient By Country Population. Retrieved from: http://worldpopulationreview.com/countries/gini-coefficient-by-country/ (accessed 30 October 2019).

8. Global inequity facts. Inequality.org Retrieved from: https://inequality.org/ facts/global-inequality/ (accessed 30 October 2019).

9. Global wealth report 2019. Credit Suisse. Research Institute, October 2019. Retrieved from: https://www.google.com/url? sa $=\mathrm{t} \& \mathrm{rct}=\mathrm{j} \& \mathrm{q}=\&$ esrc $=\mathrm{s} \&-$ source $=$ web $\& c d=2 \& c a d=r j a \& u a c t=8 \& v e d=2$ ahUKEwjp 55 vh 8 MPlAhXpyKYKHUroDqwQFjABegQICxAG\&url=https\%3A\%2F\%2Fwww.credit-suisse. com $\% 2$ Fmedia $\% 2$ Fassets $\% 2$ Fcorporate $\% 2 \mathrm{~F}$ docs $\% 2$ Fabout-us $\% 2$ Fresearch $\% 2 \mathrm{~F}$ publications\%2Fglobal-wealth-report-2019-en. pdf\&usg=AOvVaw2VwCNo8WRWHRSaFABx_Sr8 (accessed 30 October 2019)

10. Oxfam Briefing Paper (2017). AN ECONOMY FOR THE 99\%). Retrieved from: https://www.oxfam.org/sites/www.oxfam.org/files/file_attachments/bpeconomy-for-99-percent-160117-en.pdf (accessed 30 October 2019).

11. Oxfam: World's richest 26 own same wealth as poorest half. Retrieved from: https://www.aljazeera.com/news/2019/01/oxfam-world-richest-26-wealthpoorest-190121054249908.html (accessed 30 October 2019).

12. The Changing Wealth of Nations: Measuring Sustainable Development in the New Millennium. Environment and Development. World Bank, 2011. Retrieved from: https://openknowledge.worldbank.org/handle/10986/2252 (accessed 30 October 2019).

13. Theil H. Economics and Information Theory / H. Theil. - Amsterdam: North-Holland, 1967. $-488 \mathrm{p}$.

14. World Development Report 2019. Retrieved from: https://www.worldbank.org/ en/publication/wdr2019 (accessed 30 October 2019).

15. World GDP per capita Ranking 2019. Retrieved from: http://statisticstimes. com/economy/projected-world-gdp-capita-ranking.php (accessed 30 October 2019).

16. World Happiness Report 2019. Retrieved from: $\mathrm{https}$ :/www.google.com/url?sa $=\mathrm{t} \& \mathrm{rct}=\mathrm{j} \& \mathrm{q}=\& \mathrm{esrc}=\mathrm{s} \&$ source= $=\mathrm{web} \& \mathrm{~cd}=4 \& \mathrm{cad}=\mathrm{r}-$ ja\&uact $=8 \&$ ved $=2$ ahUKEwjVl_C1-8PlAhVmyqYKHaYpCgkQFjADegQIABAB \&url=https $\% 3 \mathrm{~A} \% 2 \mathrm{~F} \% 2 \mathrm{~F}$ worldhappiness.report $\% 2 \mathrm{Fed} \% 2 \mathrm{~F} 2019 \% 2 \mathrm{~F} \&$ usg $=$ AOvVaw1n8QVn6lkvFQgkypc08TO- (accessed 30 October 2019).

17. 5 shocking facts about extreme global inequality and how to even it up. Oxfam international. Retrieved from: https://www.oxfam.org/en/5-shocking-factsabout-extreme-global-inequality-and-how-even-it (accessed 30 October 2019). 